1 When the Managerial Merry-go-round Stops: A Case Study of how Disconfirming

John P. Mills

5 University of Essex, School of Sport, Rehabilitation, and Exercise Sciences, Wivenhoe, Colchester, UK

7

8 Corresponding author:

9 John P. Mills,

10 School of Sport, Rehabilitation, and Exercise Sciences

11 University of Essex,

12 Wivenhoe Park,

13 Colchester,

14 CO4 3SQ

15 UK.

16 research@johnpmills.co.uk

17

18

19

20 Keywords: Self-concept; Identity accumulation theory; Identity erosion; self; Soccer;

21 Coaching.

22

23 
When the managerial merry-go-round stops.

1

\section{Abstract}

Due to the highly competitive nature of top-level football (i.e., top domestic league or international standard) expert football managers often undergo several disconfirming episodes throughout their careers (e.g., job loss, public criticism, unsuccessful interviews or career moves). However, little is known about how such episodes are experienced and impact identity. Therefore, the following case study aims explore the affect, if any, disconfirming experiences had on the identities and self-concept of three, unemployed, top-level football managers. Narrative constructs reveal that during disconfirming episodes' managers experience feelings of anger, a loss of self-respect, disappointment, and sadness. Further, they also report how confusion regarding their future career prospects leaves them in a state of limbo (i.e., identity interference), whereby they were unsure as to how, when or if they should cease their commitment to a valued identity. 
When the managerial merry-go-round stops.

\title{
When the Managerial Merry-go-round Stops: A Case Study of how Disconfirming Episodes Affect the Identities of Expert Football Managers
}

\author{
There are only two types of manager. Those who have been sacked and those who will be in \\ the future. Howard Wilkinson, Chair of the League Managers Association.
}

Recent years have witnessed a surge of public interest in the career trajectories of football managers ${ }^{1}$. Betting companies offer odds on who will be sacked first, the sports sections of newspapers and websites are filled with stories about which manager is insecure in their job, and fans around the world pontificate with friends and colleagues over their respective manager's future. Despite this considerable public interest and calls from several scholars (Kenttä, Mellalieu, Roberts, 2016; Lavallee, 2006; Gordon \& Lavallee, 2004), little research has thus far been conducted within the population of sports managers (Lavallee, 2006). Instead, the extant literature has primarily focussed on athletes' experiences of adjustment difficulties during disconfirming experiences (e.g., career termination, unsuccessful junior to senior transitions, club initiated transfers, and injury). Research conducted within an athlete population, however, has argued that the competitive environment of elite sport limits opportunities for post-career planning (Lavallee, 2005; Lavallee, Gordon, \& Grove, 1996; Taylor \& Ogilvie, 2001). Given that both managers and athletes operate within the same environment - albeit facing different challenges - it is likely that managers will report a similar lack of post-career planning. Lavallee (2006) lends weight to this notion and suggests that managers report an unwillingness to consider a career outside of management. Given that the average tenure of managers in the English football leagues is 1.66 years (League Managers Association, 2017) and that 50\% of first time managers fail to achieve a second managerial position (Bridgewater, 2010), this is problematic. Further, Lavallee, Gordon, and Grove (1997) suggests that while working in management may allow sport-related identities and social support networks to remain intact, managers are vulnerable to identity related difficulties should they cease to maintain a career in management.

Shavelson, Hubner and Stanton (1976) define self-concept as the way a person generally perceives him- or herself, based on their experience and interpretation of their environment. The primary role of such generalisations is to organise and guide the processing of self-related information, acting as a selective mechanism which determines how information is structured and ultimately, attended to (Strachan, Sheilds, Beatty, \& Glassford, 2012). As such, the process is relatively fluid and is in part influenced by the views of significant others and one's own behaviour. In contrast, identities are formed at a more conscious level and are based on the individual's traits and characteristics, their social relations, and the roles and social group memberships in which they occupy. As such, identities help us to make meaning and evaluate what is important to us within a context (Oyserman, Elmore, \& Smith, 2012). Although the self-concept includes the cognitive generalisations held about a specific role, role-identity refers to the self-descriptive and internalised social role an individual occupies (Owens, Robinson, \& Smith-Lovin, 2010). Like a police officer with a criminal or a parent and child, each role occupied is accompanied with role expectations, reinforces membership, and creates a unique identity (Hogg, 2006).

Within football, Mills (2015, p. 610) describes the social pressures unemployed managers experience and the diminutive influence this may have on identity:

\footnotetext{
${ }^{1}$ Within the present manuscript the term 'Football Manager' refers to those who are involved with multiple aspects of football club management rather than primarily coaching related activities (i.e., Head Coach).
} 
When the managerial merry-go-round stops.

"I still thought of myself as primarily a coach, but something had changed. While back home everyone had known me as a coach, here I was being judged for pontificating to other coaches I had met without 'walking the walk.' My new peers were not abusive, they just did not see me as a coach and openly challenged my claims: usually through the half-mocking banter of new friends. Why should they think of me as a coach, I was still calling myself one without doing any coaching? I struggled to argue my point, but it was of no use, without context the role meant nothing - like a teacher and a student within a school, the roles of coach and player are defined within the social structure of the club."

For McCall and Simmons (1966, p. 67), role-identity encompasses the "character and the role that an individual devise for himself as an occupant of a particular social position" and includes an "imaginative view of himself as he likes to think of himself being and acting as an occupant of that position". Although identity is often discussed in the present (i.e., what is true of the individual now), they need not be. Identities can also be focused on the past (i.e., what used to be true of the individual) and the future (e.g., the person the individual expects, hopes or feels obliged to become; or the person one fears one may become). Oyserman and James (2011) take this a step further by suggesting that the concept of the future self also contains aspects of what we aspire to in terms of our potential self. Given the virtually unlimited identities available, Oyserman and James suggest that individuals limit their aspirations to focus on key identities to avoid disappointment.

It is important to note, however, that this view of identity described here is one based on theories of identity internalisation (i.e., Identity Accumulation Theory, Thoits, 1983; Identity Control Theory, Burke, 1991; Identity Theory, Stryker, 2007; Role Identity Theory, McCall \& Simmons, 1966) rather than those which place greater emphasis on social context (i.e., Affect Control Theory, Heise. 2007; Situated Identity Theory, Alexander \& Knight, 1971; Social Identity Theory, Tajfel \& Turner, 1979; Turner, 1982). Within theories of identity internalisation, individuals may hold multiple identities which make up the self-concept, one's theory of one's personality, and what one believes is true of one's self (Oyserman et al., 2012). As individuals tend to occupy multiple roles and group memberships, identities are used to help summarise one's behaviour within a particular context. Further, the processes described are two-way with individuals also relying on this information to make evaluations, decisions, predictions, and inferences about the self (Fazio \& Olsen, 2003).

Although holding multiple identities can offer opportunities for "social interaction, economic mobility, and the accumulation of skills and abilities", combining identities is not without its difficulties (Settles, 2004, p. 487). When two or more identities are perceived to be in conflict, identity interference can occur (Van Sell, Brief, \& Schuler, 1981). An obvious example of this process can be witnessed in the workplace, as new parents attempt to grapple with the often conflicting roles of mother/father and employee. To be clear, the roles themselves do not constitute identity, but rather it is the depth to which the expectations associated with the role are internalised and prioritised by the individual as occupant. For those, like the managers discussed within this manuscript, the role develops more meaning and becomes part of the self (Stryker \& Burke, 2000). However, when a potential self proves unattainable (e.g., an athlete who can no longer play or a manager who cannot get a job), selfesteem is threatened and the identity eroded. As such, the individual may choose to let go of said identity to ease cognitive dissonance and regain self-esteem (Oyserman \& James, 2011; 
When the managerial merry-go-round stops.

Stets \& Burke, 2012). However, a willingness to relinquish an identity, be it past, present, future or possible, is likely based, in part on the commitment to said identity (Stryker, 2007). For managers, who have attained repeated categorisation and evaluation of a behaviour by the self or others since childhood, letting go of an identity can be particularly problematic (Stryker, 2007).

\section{The Present Study}

In response to calls for more research into the affect of disconfirming episodes on coaches (Lavallee, 2006; Wylleman, Lavallee, \& Alfermann, 1999), the aim of this study is to explore how unemployment and the associated experiences has affected the identities of a sample of expert football managers. Given their propensity to progress into management from a professional playing background, the frequency in which they transition in and out of sport, and the internal and external pressures faced, football managers provide a unique sample to explore such processes. In achieving its aim, this study will be the first to detail how disconfirming episodes affect the identities of former top-level football managers. Further, this study will highlight the episodes experienced, the affect these episodes have had on identity and overall self-concept, and the psychological processes experienced more broadly.

\section{Method}

Following ethical approval from a UK University Ethics Committee, 153 managers were identified as having managed in the English Premier League at the point of recruitment. Of this group 53 managers met Abraham, Collins, and Martindale's (2006) criteria of expertise (i.e., at least 10-years' top-level management experience) and had gained at least some of this top level experience in a full-time coaching role within the English Premier League. The criteria were imposed as it provided a narrow focus and offered the greatest opportunity to recruit those who had dedicated the considerable time and effort to become a manager, were publicly known for their profession, had experienced a disconfirming experience in management, and were contactable via a gatekeeper. 26 of these individuals were currently employed and three were deceased, which left 24 managers who were currently unemployed and eligible for participation at the point of recruitment. Of the 24 individuals contacted via the League Managers Association, four responded and three agreed to participate.

Following verbatim transcription of the three interviews (median duration 60-minutes), the author undertook a holistic content and form analysis using the protocol proposed by Lieblich, Tuval-Mashiach, and Zilber (1998). Holistic-content analysis focused on the content of three interviews to reveal the psychosocial processes that affected self-concept during disconfirming experiences. In accordance with Lieblich et al. (1998), each transcript was read several times to initially form a general impression of the text, identify patterns, and enable the generation of critical events that captured affected self-concept and individual identities. Based on these critical events, stories were formally structured to allow for the interpretation of narratives (Lieblich et al., 1998). According to Coffey and Atkinson (1996, p.71), by analysing the form of the content (i.e., holistic-form analysis), the temporal order of stories can be explored for key "turning points". Further, by examining how the story is told and structured, information can be gleaned about the wider social group in which the storyteller belongs (Coffey \& Atkinson, 1996).

Within the present study, a critical realist position was adopted with the experiences discussed considered from a single ontological reality, but subject to multiple interpretations that are influenced by the way participants made sense of and retold the events and experiences 
When the managerial merry-go-round stops.

discussed (Braun and Clarke, 2006). Within the present study, a critical realist position was adopted with the experiences discussed considered from a single ontological reality, but subject to multiple interpretations that are influenced by the way participants made sense of and retold the events and experiences discussed (Braun and Clarke, 2006). However, these multiple interpretations As Bhaskar $(1975,16)$ states, "knowledge is a social product, produced by means of antecedent social products". By stratifying knowledge as both process and outcome, Critical Realism breaks from qualitative traditions, which are often predicated on the assumption that interpretivist epistemologies are the necessary result of constructivist ontologies (Bhaskar 1989). Critical realism, then, rejects the idea of multiple realities, in the sense that realities are independent and incommensurable worlds that are socially constructed by different individuals or societies (Maxwell, 2012). However, critical realism is compatible with the idea that there are different valid perspectives on reality. In taking this position, it is important to note, that, whilst multiple interpretations of events may be considered, the events and experiences are considered to be based in reality as opposed to the product of imagination (Wiltshire, 2018). As such, critical realism finds a common ground between interpretivism and post-positivism in that, claims to truth are both sought, compared, and resolved through rational discussion and debate - although this position is not without criticism (see Chalmers 1988; King 1999). That said, in taking a critical realist approach, qualitative researchers may begin to discuss causality, whilst avoiding deterministic, linear and simplified descriptions of cause (Wiltshire, 2018). With this in mind, such a position is particularly suited to those working with organisations seeking initial advice on often-messy issues (Daniels, Bell \& Horrocks, 2018).

Due to the exploratory nature of the research, the perceived interest in the case itself, minute population, and lack of prior literature to draw upon, an intrinsic case-study design was adopted (Stake, 1995). According to Schwandt (1997, p. 12), a case may be a "person, process, event, group, organization, and so on". In this instance the case is a single group of top-level professional football managers who have faced a disconfirming experience (i.e., job loss). Rather than focusing on quantifying information, case-study research seeks to explore the how and why questions. As previously discussed, a similar stance was adopted when analysing the data with holistic content analysis used to identify the what and holistic form analysis to identify the how (Smith \& Sparkes, 2012). Within the present study, a critical realist position was adopted with the experiences discussed considered from a single ontological reality, but subject to multiple interpretations that are influenced by the way participants, experienced, made sense of, and retold the phenomena discussed (Braun and Clarke, 2006).

Unlike other forms of case-study, intrinsic case-studies are not interested in extending theory per se and acknowledge that there may be limited transferability (Baxter \& Jack, 2008). Rather, the case is selected not because it is representative of other cases, but because of its uniqueness, which is of genuine interest. As such, the purpose of case study is not to represent the world, but represent the case and identify the particular challenges faced by the case in question. In doing so, it is important to describe the case in detail and fulfil the conceptual responsibilities required of the method. Within the present study, this includes conceptualising the study, selecting the research questions to emphasize, seeking patterns within the data to locate and develop key events, consider alternative explanations, and develop assertions about the case (Stake, 2000).

It is also worth noting that such an approach is primarily used within difficult to access samples and is focused on gaining a better understanding of unique individuals or situations (Crowe, Cresswell, Robertson, Huby, Avery \& Sheikh, 2012). Such an approach is also useful 
When the managerial merry-go-round stops.

when reporting findings from a previously inaccessible sample or where continual access is problematic (Holt \& Hogg, 2002). Instead, intrinsic case studies often provide the first step in uncovering a new phenomenon before more traditional instrumental or collective case study approaches, which seek to examine between case differences and present more conclusive evidence (Baxter \& Jack, 2008). Given the highly homogenous nature of the sample, minute number of individuals who hold a similar position or work at a comparable level, the public interest in the experiences of football managers, and lack of prior research, an intrinsic case study approach is appropriate within the present study.

\section{Interviewer Credibility}

As I, the author and primary researcher, am the instrument through which the data was collected, I have adopted a personal voice within this subsection to express my reflections on the process (Rosenberg, 1979). I do so in order to present information regarding my prior experiences, which may influence the interpretations made (Krane, Greenleaf, \& Snow, 1997). Therefore, my academic background is in psychology and before entering academia, I had spent a decade working as a coach in amateur, youth and semi-professional football (Mills, 2015). As such, I have some knowledge of the demands of football management and was aware of much of the technical language used by the participants. It is worth noting that I believe my prior experience helped build an initial rapport with the participants as it established me as a cultural insider (Hammersley \& Atkinson, 1995). In fact, each interview began with the participants interviewing me on my background. Although not how I had planned the interviews, on reflection, I am confident that the process helped to assure the participants of my ability to consider the situations discussed from their viewpoint (Eklund, 1993; Fontana \& Frey, 1994). Further, I believe this early interaction put the participants at ease and reassured them that I would handle their stories sensitively, although honouring the complexities of the lived experiences presented (Smith \& Sparkes, 2012). However, I am under no illusion that their interviewing me may have also held a secondary purpose. As successful and arguably elite individuals (see Harvey, 2011), I suspect their pre-interview of me allowed them the opportunity to reinforce their status before examining whether as Schoenberger (1992, p. 217) states " $[\mathrm{I} \mathrm{am}]$ an obscure academic who possess, as far as the interviewee is concerned, no threat."

\section{The Managers}

In the following section I briefly provide context to the playing and management experiences of the three managers ${ }^{2}$. Against this backdrop, the focus is then turned onto the moment in which the managers interviewed lose their respective jobs and the impact this has on both them and their significant others. Finally, the influences of these experiences are analysed in The end of a job - and possibly a career.

I start with Billy who is in his 50s and resides in England. He is educated to undergraduate degree level and played professionally for a wide range of clubs. His playing career spanned nearly two decades in league and international football. Towards the end of his playing career, Billy began to plan for a career in management and worked abroad whilst completing his coaching qualifications. He then went on to manage a range of top-level teams and internationally. At the point of the interview his career was on a downward trajectory and

\footnotetext{
${ }^{2}$ Please note that in the interests of confidentiality pseudonyms are used throughout (i.e., both names, clubs, and contacts) and some details are withheld or kept purposefully vague.
} 
When the managerial merry-go-round stops.

he had found himself out of work for four of the past five years. Although currently unemployed, he spends his time preparing for his next position.

Like Billy, Alex is also in his 50s and played professionally. However, although Billy competed at the highest level as a player, Alex did not reach the same heights. He did, however, have a respectable career in the lower leagues. Although he had a long career, he was not always a regular (i.e., someone who plays every game) and struggled to make an impact as a player. After a number of years playing within a lower league club, Alex was presented with an opportunity to coach coming back from injury. Despite having arguably the least playing impact of the three managers interviewed, Alex had held managerial positions at the highest level, continually, for nearly two decades and had accrued over 600-games in management. He had also managed internationally and has a global reputation.

Lastly, Daniel who, in his late 60s, was the eldest of the three managers interviewed. Daniel started his playing career in the 1960s and in his own words he "never fulfilled his potential". After a promising start to his playing career Daniel had ended up playing non-league football in his late 20s. Daniel felt at the time that he was too young to be a manager (indicating a pre-existing idea of what or who a manager should be), citing both his young age (late 20s) and that he was still playing as evidence he was unsuitable for the role. Daniel completed what he termed "his apprenticeship" in non-league football before moving on to a full-time coaching position. Daniel has worked in every division in English football across a period of nearly three decades. He has also amassed the most games of any of the managers interviewed.

\section{The End of a Job - and Possibly a Career.}

At the time of interview, the managers had been out of managerial employment for differing lengths of time. Alex had been in high profile employment until recently (i.e., $<12-$ months) and as such his identity as a manager was less threatened than the other two participants. Throughout the interview he appeared very confident that he would find employment again shortly, stating that, "I always know what I am going to do next". Further, since being interviewed for this study he has taken on another full-time managerial position. In contrast, Billy had been out of management for nearly four out of the previous five years and Daniel nearly nine years [at the time of interview]. They both recalled the difficulty in losing their respective positions and the impact this had on their families:

"Researcher: How do you react to being asked to leave a club?

Billy: I was angry, I was disappointed that I didn't see it through and to be honest we would have probably survived with me in charge... You feel angry and disappointed. At Rovers, I felt more aggrieved to be fair because I'd been there for a long time. You've got to be angry. At United I was gutted too... I mean I had a safe job... I was loved and was doing well. That was soul destroying that."

Daniel spoke of how his losing a high-profile managerial position impacted upon his selfesteem, family, and feelings that the public perceived him to be a bad person' based on his team's performance:

"Losing a job is a terrible experience. It must be for anybody in any job not just football. The difference with football is it's the profile, it's the press, the children at school, the accusation of failure. It's hard to take publicly you have failed. You've also lost respect." 
When the managerial merry-go-round stops.

Both Daniel and Billy also demonstrated signs of identity loss and stated that they still thought of themselves as managers; this despite not being actively employed within the profession for some time (Berzonsky \& Papini, 2014; Douglas, 2009). According to Stryker \& Serpe (1994), the loss of a preferred or dominant role may also negatively affect a person's overall selfconcept. Given their lack of ability to fulfil their ideal identity image and occupant of a desired role, it is also likely that both Daniel and Billy are experiencing a degree of cognitive dissonance (Leary \& Tangney, 2003). As such, it is likely that such individuals may experience post-career termination identity issues, which negatively impact upon self-worth and selfefficacy (Cast \& Burke, 2002). At the time of interview Billy's identity is intertwined with the role of football manager. When trying to emphasise this point he draws the following analogy:

"I always say to people managers are a bit like priests, Catholic priests, you can never be defrocked as a Catholic priest unless you get involved in something dodgy but you're always a priest and although you retire you're still a priest, it's just you haven't got a parish. Managers are like that. We're managers all our lives just we haven't got a football club. You're not anything else. We're priests without parishes till the day we die."

Similarly, Daniel still considers himself a manager despite being out of management for the longest period of time. He does doubt, however, whether anyone else still sees him this way, "I just think of myself as a football manager, but I think in the eyes of everyone else, of course my identity's definitely changed, of course." These narratives reflect the participant's membership to the role of football manager. As Oyserman et al. (2012) state, role identity is a two-way process that requires others to play a complementary role. Like a teacher without a student or a parent without a child, the managers within the present study felt dissonance in their position as a manager/coach without others (i.e., a team/players) to confirm their identity within the role of football manager:

"Daniel: It's very difficult to come to terms with it [leaving the game]. I just think of myself as a football manager, but I think in the eyes of everyone else of course my identity's definitely changed. As I've been out of the game for a few years yes I can go into a supermarket now, even locally people have forgotten who I am. I'm sure it happens to other people in other walks of life whether in films or television or whatever, they're a B star now, they're not at the top of the list anymore."

Both Billy and Daniel appear to have experienced a form of identity foreclosure, whereby their identity as a 'football man' is so firmly rooted that they find it difficult to consider themselves working in any other capacity (Kroger \& Marcia, 2013) or adopting alternate identities (Cosh, LeCouteur, Crabb, \& Kettler, 2013). This is consistent with the participants interviewed by Agnew and Drummond (2015, p. 83) who concluded "that one does not stop being a footballer simply because they have retired from the sport". For example, Billy described a recent conversation with a friend:

"I was asked the other day "what are you going to do now?" and I thought nothing of it at the time. But what he meant was, his impression was, well what are you going to do for a job now that you're no longer a manager. Erm, so it's a tough one. You're out 
When the managerial merry-go-round stops.

of work 2-years and then its 3-years, then it's 4-years and before you know it, you're thinking well am I working again or not. It's not a nice process. The longer it goes on the more you think well, should I retire, I'm not sure, I don't know whether I've been retired or not."

In addition to still holding a managerial identity, Daniel discussed that he was 'addicted' to football as a player. They concluded that such comments likely reflect an individual having devoted so much of their time to their chosen sport, that they had become defined by it. When asked if he would manage again, Daniel said that he would, but it was unlikely he would be able to do so in the same capacity as he had done in the past. "I could just about do it or I think I could, but maybe my health wouldn't allow me to." He is also at a stage in his career where many of his peers are in a similar situation. Erikson's (1968) theory of psychosocial development posits that it is preferable for individuals to experience transitions at a similar stage of their life to their peers. Daniel's peers also find themselves at a similar phase and as such are able to support one another through the process. Despite his desire to manage again, Daniel has shown flexibility, is realistic about his capabilities and feels that he was 'lucky' that he had always been offered some form of employment within football, "I think I have to be sensible and you have to come to terms with it [no longer being a manager]." Furthermore, his transition out of the game has been gradual, with involvement in media work relating to the sport, which has allowed him time to incorporate new roles into his existing identity. This is consistent with Krane, Greenleaf, and Snow (1997) who identified that the development of new roles into an individual's existing identity was a critical factor in managing key life transitions and periods of unemployment.

In contrast, Billy found himself without employment at a time in his life when many of his peers are employed. He is reluctant to give up on his career and is unsure if he has been forcibly retired. Studies report that such feelings have been shown to exacerbate negative emotions within an athlete population (Ronkainen, Kavoura, \& Ryba, 2016; Park, Lavallee, \& Tod, 2012). Despite a perceived lack of alternative options, Billy appeared to be considering the point that he would need to find alternative employment: "it's a tough one and the longer it goes on, the longer you think well how do I retire or have I not retired, I'm not sure I don't know whether I've been retired or not". Although there is evidence that future planning assists players with their transition from the game (see Grove et al., 1997; Sinclair \& Orlick, 1993) none of the managers involved in the present study reported any encouragement to look beyond a career in management. Unlike players, managers do not necessarily know whether their career has ended, which appeared to cause distress to the managers involved within the present study.

Although Daniel and Alex showed some flexibility in their career choices, Billy appeared to wear his commitment to his unfulfilled identity as a football manager as a badge of honour. Although Billy has found it difficult to come to terms with his professional decline, he finds himself in a conflicted position whereby he takes comfort from the emotional turmoil he faces when trying to stay in the game, also acknowledging the discomfort this creates for those around him:

"Researcher: Do you think your experiences of leaving football clubs has affected you as a person?

Billy: Erm, you'll have to ask my partner that to be fair.

Researcher: What do you think she'd say? 
When the managerial merry-go-round stops.

Billy: I don't know erm, you're more susceptible to feeling sorry for yourself because you get up every day saying what are you going to do today... I mean I don't. I go to matches, because you're supposed to keep involved. I go to matches, but she says why do you go, why do you bother going to games anymore? It's like self-harming. You go because you're a manager, you're an ex-manager, but you're not involved and watching other people do your job is like self-harming. She says why do you go to games, why do you self-harm yourself, but it's something you've always done - I've always gone to games on Saturday since I was playing, managing, scouting, I've always gone to games and I continue to do it because that's what I think I should do. I take my son with me now and he enjoys football, so to an extent, it takes a little bit of the edge off. But there are times that you're sat there thinking about whether you'll ever be able to do that again, you know. You have more time and there is more time to feel sorry for yourself."

Within the previous quote, Billy describes a sense of emotional loss, which is likely due to his inability to achieve his ideal identity image and threatened self-concept. Further, in continuing to attend games, Billy may be, in part, attempting to offset feelings of separation from significant others (i.e., athletes and coaching staff; Lavellee, Gordon, \& Grove, 1997). As the present fails to meet his expectations, his identity is fixed in both the future and the past (Oyserman et al., 2012), which creates an unfulfilled present. For Billy, living in the present would mean abandoning his aspirations of returning to management and fulfilling his idealised image of self (Leary \& Tangney, 2003). Billy sees little choice but to chase a career in football management and sees little purpose in widening his interests - after all football is the only profession he has ever known. Previous studies within an athlete population report that those whose self-concept does not extend beyond the sporting domain may experience lowered selfesteem and a general decrease in life satisfaction (Lavallee et al., 1997). Billy feels trapped and the longer his position is maintained, the greater the attendant shame he is likely to experience (Kroger \& Marcia, 2013).

\section{Discussion}

The purpose of the present study was to examine the career histories of expert football managers and explore how disconfirming experiences affect identities. The findings suggest that expert football managers may extend an athletic identity beyond their playing careers into their management roles, which on occasion, may result in acute identity narrowing. The results presented here also suggest that, during disconfirming experiences, like athletes, managers experience psychological discomfort (e.g., feelings of anger, a loss of self-respect, disappointment, and sadness). During these episodes, expert football managers face personal feelings of dejection and loss (i.e., separation from the group), and often experience public denigration that greatly impacts upon them as individuals and also their family. Unlike players, managers are often held solely responsible for team failure. However, rather than experiencing support, the findings suggest that managers are often cast aside and left to experience these personal stressors, identity threats (i.e., no longer being employed as a manager), media intrusion, and financial concerns without organisational assistance.

When experiencing such processes, Steele, Spencer, and Aronson (2002) suggest individuals may trigger behaviours, which seek to cognitively resolve the stressor. This is also applicable to identity, whereby identity threat often results in the threatened individual adopting behaviours that attempt to prove one's membership (Bosson, Vandello, Burnaford, 
When the managerial merry-go-round stops.

Weaver, \& Wasti, 2009). Billy's compulsion to attend matches is perhaps an example of such behaviour. However, it is worth noting that group membership need not be limited in this instance to that of a football manager. In finding alternative and arguably age-appropriate employment within football (i.e., Director, Pundit, and Scout), Daniel may have attempted to resolve threats to his identity by maintaining his self-view as a 'football man'.

Depending on the length of time away from the game, managers may experience such threats for a prolonged period of time, which appears to have an eroding effect that may be mediated by strength of identity (i.e., hierarchical identity salience, length of time, and frequency of confirming experiences) and societal expectations (e.g., it is more social acceptability for a 65-year old manager to be long-term unemployed than it is a 45-year old). Although identity resolution approaches may provide short-term comfort, they are not a longterm strategy. Without external identity reinforcement, prolonged attempts to resolve identity threat may result in cognitive dissonance (Oyserman \& James, 2011; Stets \& Burke, 2012). Oyserman and James (2011) suggest that when a potential self proves unattainable, individuals may select to discard such an identity, however, the findings of the present study do not appear support this. At the time of interview, the managers demonstrated an unwillingness to relinquish identities associated with that of fulfilling the role of football manager. It is worth noting, however, that Oyserman and James (2011) do not state the length of time or the frequency of identity of erosion required to let go of an identity. As such, it is likely a highly subjective process that may be largely reliant on the strength of association towards said identity (Stryker, 2007).

Given the psychological discomfort felt and the ambiguity in the length of time in which such feelings may be experienced, understanding the influence role-identity has on managers during disconfirming experiences is critical in supporting the psychological well being of managers. Further research is therefore needed to examine the ramifications of disconfirming experiences based on the strength of managerial identity at different time-points. Longitudinal research that assesses the impact of identity erosion on the strength of association towards said identity is also warranted. Research examining how sport psychologists, football clubs, and national associations can support the reduction of the types of psychological discomfort discussed, both for the manager and their family, is also required. Further research examining whether the experiences discussed here are also found within expert managers within other sports and in other countries is also required. Currently, managers are treated in the same way or worse than as those who, in most other industries, have committed the most serious of gross misconduct. Given that managers usually lose their jobs based on the team's performance alone, treating individuals in such a way is unacceptable and likely in breach of employment law. Therefore, football should consider the present culture adopted and aim to provide a more supportive and sympathetic environment. In the short-term, psychological support should be offered during disconfirming experiences to both managers and if appropriate, their family. None of the managers discussed any encouragement to plan for the end of their career, which given the precarious nature of their employment seems particularly reckless. Providing managers with support to expand their identities beyond football may also prove beneficial to those both at the end of their careers or who find themselves in a perpetual state of cognitive dissonance.

\section{Conclusion}

The present study is the first to explore how disconfirming experiences affect the identities of expert football managers. The findings also suggest that expert football managers 
When the managerial merry-go-round stops.

1 may have extended a sporting identity beyond their playing careers into their management 2 roles. Despite experiencing disconfirming experiences each of the managers interviewed still 3 considered themselves to be managers, with two in particular stating that they would always 4 be managers and were addicted to the game. This suggests that football management and at 5 least for the individuals interviewed, has become part of the self and more than a job. Further, 6 during dis-confirming transitional experiences, like athletes, managers experience 7 psychological discomfort (e.g., feelings of anger, a loss of self-respect, disappointment, and 8 sadness). Unsurprisingly, expert football managers also face personal feelings of dejection and 9 loss (i.e., separation from the group) during periods of unemployment, while both they and 10 their family may experience public denigration. Depending on the length of time away from 11 the game, managers may also experience cognitive identity-related dissonance due to the 12 inability to fulfil a role that has become synonymous with their narrowed identity. As such, 13 understanding the influence role-identity has on managers during periods of change and 14 transition is critical in supporting their psychological wellbeing. Therefore, further research is 15 needed to examine the ramifications of career transitions based on the strength of managerial 16 identity at different time-points, and whether the psychological discomfort discussed within 17 the present study can be reduced via the proposed interventions. 
When the managerial merry-go-round stops.

\section{Reference list}

Abraham, A., Collins, D., \& Martindale, R. (2006). The coaching schematic: Validation through expert coach consensus. Journal of Sports Sciences, 24(6), 549-564.

Agnew, D., \& Drummond, M. (2015). Always a footballer? The reconstruction of masculine identity following retirement from elite Australian football. Qualitative Research in Sport, Exercise and Health, 7(1), 68-87.

Alexander, C., \& Knight, G. (1971). Situated Identities and Social Psychological Experimentation. Sociometry, 34(1), 65-82

Baxter, P., \& Jack, S. (2008). Qualitative Case Study Methodology: Study Design and Implementation for Novice Researchers. The Qualitative Report, 13(4), 544-559.

Bhaskar, R., (1975). A Realist Theory of Science, $2^{\text {nd }}$ edition, London: Verso.

Bhaskar R. (1989) The Possibility of Naturalism, 2nd edition, Brighton: Harvester

Berzonsky, M.D., \& Papini, D.R. (2014). Identity Processing Styles and Value Orientations: The Mediational Role of Self-Regulation and Identity Commitment. Identity, 14, 96112.

Bosson, J.K., Vandello, J.A., Burnaford, R.M., Weaver, J.R., \& Wasti, S.A. (2009). Precarious manhood and displays of physical aggression. Personality and Social Psychology Bulletin, 35, 623-634.

Braun, V., \& Clarke, V. (2006). Using thematic analysis in psychology. Qualitative Research in Psychology, 3(2), 77-101.

Bridgewater, S. (2010). Football management. Basingstoke and New York, Palgrave Macmillan.

Burke, P.J. (1991). Identity Processes and Social Stress. American Sociological Review, 56(6), 836-849.

Burke, P.J., \& Tully, J.C. (1977). The Measurement of Role Identity. Social Forces, 55(4), 881-897.

Cast, A.D., \& Burke, P.J. (2002). A Theory of Self-Esteem. Social Forces, 80(3), 1041-1068.

Chalmers, A. (1988). “Is Bhaskar's Realism Realistic?” Radical Philosophy 49: 18-23.

Coffey, A., \& Atkinson, P. (1996). Narratives and stories. In Making sense of qualitative data: Complementary research strategies (pp. 54-82). Thousand Oaks

Cosh, S., LeCouteur, A., Crabb, S., \& Kettler, L. (2013). Career transitions and identity: a discursive psychological approach to exploring athlete identity in retirement and the transition back into elite sport. Qualitative Research in Sport, Exercise \& Health, $5(1), 21-42$.

Crowe, S., Cresswell, K., Robertson, A., Huby, G., Avery, A., \& Sheikh, A. (2012). The case study approach. BMC Medical Research Methodology, 11, 100-109.

Daniels, J.E., Bell, B., \& Horrocks, C. (2018). Capturing the realities of sports programmes: systematic 'messiness'? International Journal of Sport Policy and Politics, 10(4), 779794 ,

Denzin, N.K. (1978). The research act: A theoretical introduction to sociological methods. New York: McGraw-Hill.

Douglas, K. (2009). Storying my self: negotiating a relational identity in professional sport. Qualitative Research in Sport and Exercise, 1(2), 176-190.

Eklund, R.C. (1993). Considerations for Gaining Entry to Conduct Sport Psychology Field Research. The Sport Psychologist, 7, 232-243.

Erikson, E.H. (1968). Identity: Youth and crisis. New York: Norton. 
When the managerial merry-go-round stops.

Fazio, R.H., \& Olson, M.A. (2003). Implicit measures in social cognition research: their meaning and use. Annual review of psychology, 54, 297-327.

Fontana, A., \& Frey, J. (1994). The Art of Science. In: N. Denzin and Y. Lincoln, eds. The Sage handbook of qualitative research. Thousand Oaks, CA: Sage, 361- 376.

Grove, J.R., Lavallee, D., \& Gordon, S. (1997). Coping with retirement from sport: The influence of athletic identity. Journal of Applied Sport Psychology, 9, 191-203.

Hammersley, M., \& Atkinson, P. (1995). Ethnography: Principles in Practice, $2^{\text {nd }}$ edition. London: Routledge

Heise, D.R. (2007). Expressive Order: Confirming Sentiments in Social Action. New York: Springer.

Hogg, M.A. (2006). Social identity theory. In P.J. Burke (Ed.), Contemporary social psychological theories (pp. 111-136). Stanford CA: Stanford University Press.

Holt, N.L., \& Hogg, J.H. (2002). Perceptions of Stress and Coping During Preparations for the 1999 Women's Soccer World Cup Finals. The Sport Psychologist, 16, 251-271.

Jones, G. (1995). More than just a game: Research developments and issues in competitive anxiety in sport. British Journal of Psychology, 86, 449-478.

Kenttä, G., Mellalieu, S.D., \& Roberts, C.M. (2016). Are Career Termination Concerns only for Athletes? A Case Study of the Career Termination of an Elite Female Coach. The Sport Psychologist, 30(4). pp. 314-326.

King, A. (1999). The Impossibility of Naturalism: The Antinomies of Bhaskar's Realism, Journal for the Theory of Social Behaviour 29(3): 267-288.

Krane, V., Greenleaf, C.A., \& Snow, J. (1997). Reaching for gold and the price of glory: A motivational case study of an elite gymnast. The Sport Psychologist, 11, 53-71.

Kroger, J., \& Marcia, J.E. (2013). The identity statuses: Origins, meanings and interpretations. In S.J. Schwartz, K. Luyckx, and V.L. Vignoles, Handbook of Identity Theory and Research (Vol. 2, pp 31-53).

Lavallee, D. (2005). The effect of a life development intervention on sports career transition adjustment. The Sport Psychologist, 19, 193-202.

Lavallee, D. (2006). Career Awareness, Career Planning, and Career Transition Needs Among Sports Coaches. Journal of Career Development, 66-79.

Lavallee, D., Gordon, S., \& Grove, J. R. (1997). Retirement from sport and the loss of athletic identity. Journal of Personal and Interpersonal Loss, 2, 129-147.

League Managers Association (2016). End of season manager statistics 2015-2016. England. Leary, M.R., \& Tangney, J.P. (2003). Handbook of Self and Identity. New York: Guilford. Lieblich, A., Tuval-Mashiach, R., \& Zilber, T. (1998). Narrative Research. London: Sage. Maxwell, J. A. (2012). A Realist Approach for Qualitative Research, London: Sage McCall, G.J., \& Simmons, J.L. (1966). Identities and Interactions. New York: Free Press. Mills, J. P. (2015). An [AUTO]ethnographic account of constructing, deconstructing, and partially reconstructing a coaching identity. Qualitative Research in Sport, Exercise and Health, 7(5), 606-619.

Owens, T.J., Robinson, D.T., \& Smith-Lovin, L. (2010). Three faces of identity. Annual Review of Sociology, 36, 477-499.

Oyersman, D., Elmore, K., \& Smith, G. (2012). Self, Self-Concept, and Identity. In M.R. Leary, and J.P. Tangney (Eds.), Handbook of Self and Identity (pp. 69-104). New York: The Guildford Press. 
When the managerial merry-go-round stops.

Oyserman, D., \& James, L. (2011). Possible identities. In S. Schwartz, K. Luyckx, and V. Vignoles (Eds.), Handbook of Identity Theory and Research (pp. 117-145). SpringerVerlag.

Park, S., Lavallee, D., \& Tod, D. (2012). Athletes' career transition out of sport. International Review of Sport and Exercise Psychology, 6, 22-53.

Ronkainen, N.J., Kavoura, A., \& Ryba, T.V. (2016). A meta-study of athletic identity research in sport psychology: Current status and future directions, 9(1), 45-64.

Rosenberg, M. (1979). Conceiving the Self. Malabar, FL: Robert E. Krieger.

Schoenberger, E. (1992). Self-criticism and Self-awareness in Research: a reply to Linda McDowell. Professional Geographer, 44(2), 215-218.

Schwandt, T.A. (1997). Qualitative inquiry: A dictionary of terms. Thousand Oaks, CA: Sage.

Settles, I. H. (2004). When Multiple Identities Interfere: The Role of Identity Centrality. Personality and Social Psychology Bulletin, 30(4), 487-500.

Shavelson, R.J., Hubner, J.J., \& Stanton, G. C. (1976). Validation of construct interpretations. Review of Educational Research, 46, 407-441.

Sinclair, D., \& Orlick, T. (1993). Positive transitions form high-performance sport. The Sport Psychologist, 7, 138-150.

Smith, B., \& Sparkes, A.C. (2012). Narrative analysis in sport and physical culture. In K. Young and M. Atkinson (Eds.), Qualitative research on sport and physical culture (pp. 79-100). Bingley, UK: Emerald Group.

Sparkes A., \& Smith B. (2003). Men, sport, spinal cord injury and narrative time. Qualitative Research, 3, 295-320.

Stake, R.E. (1995). The art of case study research. London: Sage.

Steele, C.M., Spencer, S.J., \& Aronson, J. (2002). Contending with group image: The psychology of stereotype and social identity threat. In M. P. Zanna (Ed.), Advances in experimental social psychology (Vol. 34, pp. 379-440). San Diego, CA: Academic Press.

Stets, J.E., \& Burke, P.J. (2000). Identity theory and social identity theory. Social Psychology Quarterly, 63, 224-237.

Strachan, S.M., Shields, C.A., Beatty, J., \& Glassford, A. (2012). Is it who I am or who I am with that counts? The associations between runner and group identity with adjustment to running group disbandment. Psychology of Sport and Exercise, 13(4), 463-443.

Stryker, S. (2007). Identity Theory and Personality Theory: Mutual Relevance. Journal of Personality, 75(6),1083-1102.

Stryker, S., \& Burke, P. (2000). The Past, Present, and Future of Identity Theory. Social Psychology Quarterly, 63(4), 284-97.

Taylor, J., Ogilvie, B., \& Lavallee, D. (2005). Career transition among athletes: Is there life after sports? In J. M. Williams (Eds.), Applied sport psychology: Personal growth to peak performance (5th ed., pp. 595-615). Columbus, OH: McGraw-Hill.

Thoits, P.A. (1983). Multiple identities and psychological well-being: A reformulation and test of the social isolation hypothesis. American Sociological Review. 48, 174-187.

Tajfel, H., \& Turner, J. (1979). An integrative theory of intergroup conflict. In W.G. Austin and S. Worchel (Eds.). The social psychology of intergroup relations (pp. 33-48). Monterey, CA: Brooks/Cole. 
When the managerial merry-go-round stops.

1 Turner, J. C. (1982). Towards a cognitive redefinition of the social group. In H. Tajfel (Ed.) Social identity and intergroup relations (pp. 15-40). Cambridge: Cambridge University Press.

Ungerleider, S. (1997). Olympic athletes' transition from sport to workplace. Perceptual and Motor Skills, 84, 1287-1295.

Van Sell, M., Brief, A.P., \& Schuler, R.S. (1981). Role conflict and role ambiguity: Integration of the literature and directions for future research. Human Relations, 34, 4371.

Wiltshire, G. (2018). A case for critical realism in the pursuit of interdisciplinarity and impact, Qualitative Research in Sport, Exercise and Health, 10, 525-542.

Wylleman, P., Lavallee, D., \& Alfermann, D. (Eds.) (1999). Career transitions in competitive sports. Biel, Switzerland: European Federation of Sport Psychology Monograph Series. 
When the managerial merry-go-round stops.

\section{Appendix: Interview guide}

2 1. How did you get into sport?

3 2. How did you get into management?

4 3. Describe a typical day at a football club you've managed.

54 . Tell me about your experiences of leaving football clubs throughout your career?

65 . If the opportunity arose, would you go back into the game and if so, would you change

7 the way you lead at the next club? If so how?

8 6. How have you changed throughout your career?

9 7. Has this period away from the game changed the way you see your self?

10 8. How do you believe your players perceive you as a person?

119 . Is this different from the way you perceive yourself and if so, which is the real you?

12 10. Has this changed since you were last in a managerial position?

13 11. Do you still see yourself as a football manager/coach? Do you think this may change and 14 if so what would make you change this perception of yourself?

15 12. Do you think your experiences of leaving football clubs has affected you as a person? 